\title{
KONSTRUKSI ISLAM RAHMAH LI AL-'ALAMIN K.H. AHMAD HASYIM MUZADI
}

\author{
Ibnul Arobi*
}

\begin{abstract}
The problems raised in this paper are; how Islamic idea rabmah li al-'alamin K.H. Abmad Hasyim Muzadi; and this paper reveals that the Islamic idea of rahmah li al-'alamin is a term that is contained in the Qur'an. This idea emerges as a form of reaction or response, in order to wean the lara that is engulfing the Islamic community, especially stigmatization addressed to Islam, as a religion contained in the teachings of seeds that can foster a Muslim to commit acts of violence. As a manifestation of the universalization of Islam, in the context of Indonesia, Islam rabmah li al-'alamin takes its form as presented by Walisongo, the pattern of Islam which is propagated by means of peace-building and wisdom to the existence of local culture (Indonesia).
\end{abstract}

Keywords: Islam rahmah li al-'alamin and K.H. Ahmad Hasyim Muzadi.

\section{A. Pendahuluan}

Islam merupakan agama yang dalam pelbagai aturannya terkandung nilai yang diyakini oleh pemeluknya sebagai rahmat bagi semesta alam. Untuk itu agama tanpa terkecuali, tentunya sangat mengecam terhadap segala bentuk kekerasan. Namun, dalam realitasnya, agama yang seharusnya memberikan kontribusi besar, justru seringkali dianggap

* Dosen Tetap Institut Ilmu Keislaman Zainul Hasan (INZAH) Genggong Kraksaan - Probolingggo. 
sebagian dari masalah yang memicu terjadinya masalah tersebut. Misalnya, ektremisme, intoleransi, kebencian, dan kekerasan.

Islam, sebagai salah satu agama dengan pemeluk paling banyak di Indonesia, merupakan agama yang telah menampilkan ajarannya dalam bingkai yang sangat toleran terhadap agama-agama "kaum minoritas". Hal ini dapat dibuktikan, misalnya dengan keberadaan kaum minoritas yang diterima menjadi bagian dari masyarakat, serta diberi kebebasan untuk hidup secara damai dalam menjalankan keyakinan dari agama masing-masing tersebut.

Sikap toleran ini menjadi penting dalam membangun kultur yang demokratis. Alfred Stepan berpendapat, bahwa dalam rangka menegakkan kultur yang demokratis, maka diperlukan apa yang dimaksudnya dengan "toleransi kembar", ${ }^{1}$ yaitu lembaga-lembaga negara harus mempunyai kebebasan dalam menentukan kebijakan tanpa harus diintervensi oleh lembaga agama. Begitu juga sebaliknya, lembaga agama juga sejatinya mempunyai kebebasan dalam menjalankan pelbagai aktivitasnya tanpa intervensi dari lembaga negara, sembari menebarkan nilai-nilai yang sudah tentu sejalan dengan demokrasi.

Dalam konteks di atas, pandangan inklusif tersebut semakin diperteguh dan diperjelas oleh para founding fathers republik ini. Indonesia, oleh para founding fathers telah berupaya untuk mencari jalan yang terbaik dalam memperjelas identitas negara yang penduduknya memiliki keanekaragaman budaya, etnik, bahasa, dan agama. Hal ini tidak lain dimaksudkan untuk membangun suasana kehidupan yang aman, tentram dan damai. Hal tersebut terkongkretisasi dengan menempatkan Sila Pertama "Ketuhanan Yang Maha Esa" sebagai dasar utama dari negara Indonesia. Hal ini juga semakin membuktikan dan menunjukkan kepada kita, bahwa para pendiri negara ini bersikap sangat toleran, saling menghargai dan menghormati kepada sesama pemeluk agama yang berbeda.

Adalah K.H. (Kiai Haji) ${ }^{2}$ Ahmad Hasyim Muzadi (selanjutnya

1 Alfred Stepan, "Religion, Democracy and the "Twin Tolerations", Journal of Democracy, Vol. 11, No. 4 (Oktober, 2000), 37.

2 Kiai adalah gelar untuk ulama, pemimpin agama, pemimpin pesantren dan guru senior di Jawa. Kata ini juga digunakan untuk menghormati barang maupun binatang yang dianggap memiliki kekuatan luar biasa. Sedangkan gelar Haji, 
ditulis Hasyim Muzadi saja) dalam praktek di atas, mempunyai peranan yang sangat signifikan dalam mengintegrasikan kegiatan atau gerakan keagamaannya ke dalam pelbagai kegiatan kebangsaan secara keseluruhan. ${ }^{3}$ Atas dasar ini, Hasyim Muzadi berpandangan, bahwa perlu adanya satu agenda yang tujuannya untuk membangun kesadaran bersama (kolektif) tentang pentingnya membangun agama, negara dan umat beragama.

Islam merupakan agama yang di dalamnya mengandung nilai-nilai universal (universal values) yang menjunjung tinggi terhadap toleransi dan terciptanya perdamaian di muka bumi". ${ }^{4}$ Atas dasar ini juga, ia berpandangan bahwa agama Islam terdiri dari tiga bagian, yaitu masalah teologi atau keimanan, masalah ibadah ritual, dan masalah kemanusiaan. ${ }^{5}$ Hal yang senada juga dikemukakan oleh Machasin, bahwa Islam menurutnya merupakan tradisi yang bergerak secara dinamis dan progresif. Tradisi ini mencakup di dalamnya amaliyyah, kepercayaan, upacara perilaku, pemikiran dan tata hubungan, yang pada akhirnya akan membentuk terhadap kepribadian dari masing-masing individu pendukungnya. $^{6}$

Namun pada sisi yang lain, khususnya dari sisi trend keagamaan yang berkembang di Indonesia saat ini, ada dua wacana yang harus "diwaspadai", adalah gerakan radikalisasi agama dan liberalisasi agama. Lebih lanjut ia berpendapat bahwa, radikalisme dalam agama Islam disebabkan oleh pelbagai faktor. Pertama, faktor pengertian seseorang terhadap Islam dan penyalahgunaan Islam untuk perorangan. Hal ini diakibatkan oleh ekslusivisme Islam. Kedua, penafsiran tentang ayat lakum dinukum waliyadin. Ayat ini seringkali diartikan hanya sebagai pembenaran

merupakan gelar bagi mereka yang telah menunaikan ibadah haji ke tanah suci Makkah. Lathiful Khuluq, Fajar Kebangunan Ulama: Biografi K.H. Hasyim Asy'ari (Yogyakarta: LKiS, 2000), 6.

3 A. Hasyim Muzadi, Membangun NU Pasca Gus Dur: Dari Sunan Bonang sampai Paman Sam (Jakarta: PT Gramedia Widiasarana Indonesia, 1999), xi.

4 A. Hasyim Muzadi, “Timur Tengah dan Prospek Islam” Republika (04 September 2006).

5 Ibnu Anshori, K.H. A. Hasyim Muzadi: Religiusitas E Cita-cita Good Governance (Sidoarjo: Citra Media, 2004), 55-56.

6 Machasin, Islam Dinamis Islam Harmonis: Lokalitas, Pluralisme, Terorisme (Yogyakarta: LKiS, 2011), 1. 
terhadap agama Islam saja tanpa pengakuan terhadap eksistensi agama lain. ${ }^{7}$ Tentu, gerakan ini (radikalisme Islam) telah membawa implikasi pada rusaknya citra Islam, karena mengesankan Islam adalah agama yang kasar, keras, dan intoleran. ${ }^{8}$ Begitu juga halnya gerakan liberalisasi agama dalam Islam. Liberalisme Islam baginya, telah melonggarkan terhadap sendi-sendi aqidah dan tawhid. Pelonggaran ini membuka peluang terhadap sinkretisme atau mengacaukan pada keimanan seseorang. ${ }^{9}$

Oleh sebab itu, menurut Hasyim Muzadi, dalam merespon keduanya, maka yang harus ditampilkan dalam gugusan realitas adalah Islam yang bervisikan rabmah li al-'alamin. Konstruksi dari berislam dengan visi rabmab li al-'alamin ini merupakan nama yang built in dengan dan dalam agama Islam. ${ }^{10}$ Sebuah konsepsi Islam yang mempunyai dimensi liberasi dalam menyelesaikan pelbagai konflik global yang terjadi selama ini, karena dengan terjadinya konflik global ini, sudah barang tentu mempunyai pengaruh terhadap sistem dan sendi kehidupan umat manusia. Atas dasar deskripsi ini, maka penulis ingin mengkaji secara kritis khususnya tentang gagasan Hasyim Muzadi, yaitu Islam rabmah li al-'alamin.

\section{B. Pembahasan}

\section{Sketsa biografi k.h. Ahmad hasyim muzadi}

Hasyim Muzadi nama kecilnya adalah Ahmad Hasyim. Ia dilahirkan pada tanggal 08 Agustus 1944 di Bangilan, Tuban, Jawa Timur. Ia merupakan putra dari pasangan Muzadi dan Rumyati. Ayahnya, Muzadi merupakan warga Tuban asli. Sedangkan ibunya, yaitu Rumyati, masih keturunan dari Kiai Mas'ud, Sedan, Lasem, Jawa Tengah. ${ }^{11}$ Ia merupakan

7 A. Hasyim Muzadi, "NU, Radikalisme dan Ummatan Washata", dalam Islam Madzab Tengah: Persembaban 70 Tabun Tarmizi Taher, ed. Hery Sucipto (Jakarta: Grafindo Khazanah Ilmu, 2007), 341-342.

8 A. Hasyim Muzadi, “Kembalilah ke Gaya Walisongo”, Majalah Duta Masyarakat, Edisi II (April-Mei, 2011), 30.

9 Ibid., 30.

${ }^{10}$ A. Hasyim Muzadi, "Memperkuat NU, Memperkuat NKRI”, Aula, No. 04, Tahun XXXIII (April, 2011), 38.

${ }^{11}$ Ibnu Anshori, K.H. A. Hasyim Muzadi: Religiusitas E Cita-Cita Good Governance (Sidoarjo: Citra Media, 2004), 15. 
putra kedelepan dari sembilan bersaudara, ${ }^{12}$ yaitu Ahmad Salim (Alm), K.H. Abdul Muchith Muzadi, Hj. Musyasarah, Hj. Siti Muzayyanah, Hj. Mahmudah, Hj. Istiqomah, Hj. Siti Hanifah, K.H. Ahmad Hasyim Muzadi dan $\mathrm{Hj}$. Maftuhah. Ia juga terlahir bukan dari seorang kiai besar dan ternama, namun ayahnya dikenal sebagai pribadi yang memiliki loyalitas yang tinggi dalam membantu dan mengurusi madrasah dan acara-acara di pondok pesantren.

Pendidikan formalnya, dimulai di Madrasah Ibtidaiyah (MI) Salafiyah, Bangilan-Tuban. Belum tamat dari Madrasah Ibtidaiyah (MI) Salafiyah, yaitu menjelang kelas enam, oleh ayahnya, Hasyim Muzadi dipindahkan untuk masuk ke Sekolah Dasar Negeri (SDN) Bangilan-Tuban. Setelah tamat dari Sekolah Dasar Negeri (SDN) pada tahun 1955, yaitu diusianya yang ke-11, Hasyim Muzadi melanjutkan pendidikan formalnya di Sekolah Menengah Pertama Negeri (SMPN) di Tuban. Namun, ia mengalami kondisi yang serupa dengan waktu masih di Madrasah Ibtidaiyah (MI). Belum genap satu tahun, ia juga di pindahkan oleh ayahnya untuk menempuh studi pada program pendidikan Kulliyatul Mua'llimin alIslamiyyah (pendidikan guru agama Islam) di Pondok Modern Darussalam Gontor-Ponorogo-Jawa Timur. Di Pondok Modern Darussalam Gontor,

${ }^{12}$ Keterangan berbeda penulis temukan dalam buku yang lain, bahwa Hasyim Muzadi merupakan anak ketujuh dari delapan bersaudara. Lihat. Muhammad Shodiq, Dinamika Kepemimpinan NU: Refleksi Perjalanan KH. Hasyim Muzadi (Surabaya: LTN NU Jawa Timur, 2004), 189. Begitu juga halnya dalam buku "Membangun NU Pasca Gus Dur; Dari Sunan Bonang sampai Paman Sam”, bahwa ia merupakan anak ketujuh dari delapan bersaudara. Lihat dalam, A. Hasyim Muzadi, Membangun NU Pasca Gus Dur: Dari Sunan Bonang sampai Paman Sam (Jakarta: PT Gramedia Widiasarana Indonesia, 1999), 3. Namun, dalam buku yang lain, Hasyim Muzadi merupakan anak kedelapan dari Sembilan bersaudara. Misalnya dalam buku yang ditulis oleh Ibnu Anshori, K.H. A. Hasyim Muzadi: Religiusitas E Cita-Cita Good Governance (Sidoarjo: Citra Media, 2004), 15. Dan ketika penulis membaca buku biografi K.H. Abdul Muchith Muzadi yang merupakan kakak dari Hasyim Muzadi dijelaskan, bahwa K.H. Muchith Muzadi merupakan anak kedua dari sembilan bersaudara. Dari sini penulis menyakini, bahwa Hasyim Muzadi jumlah saudaranya adalah delapan, dengan kata lain, putra-putri pasangan H. Muzadi dengan Hj. Rumyati adalah sembilan. Lihat. Moch. Eksan, Kiai Kelana: Biografi K.H. Muchith Muzadi (Yogyakarta: LKiS, 2000), 49. Lihat juga misalnya dalam, Ayu Sutarto, Menjadi NU Menjadi Indonesia: Pemikiran K.H. Abdul Muchith Muzadi (Surabaya: Khalista, 2008), 3. 
dan di bawah bimbingan atau asuhan K.H. Imam Zarkasyi, serta di pondok yang punya prinsip "Berdiri di atas dan untuk semua golongan" ini, ia ditempa dan juga dibina dengan pelajaran pesantren yang penuh dengan disiplin yang tinggi.

Hasyim Muzadi menempuh Proses belajar di Pondok Modern Darussalam Gontor kurang lebih selama tujuh (7) tahun, yaitu dari tahun 1955 sampai dengan 1962. Dan di Pondok Modern Darussalam Gontor ini, ia sempat belajar bersama antara lain dengan Nurcholis Madjid (alm), K.H. Syukron Makmun, dan Din Syamsuddin (ketua PP Muhammadiyah). ${ }^{13}$

Sekembalinya dari nyantri (menjadi santri) di Pondok Darussalam Modern Gontor, yaitu pada tahun 1962, Hasyim Muzadi melanjutkan perjalanan intelektualnya dengan menimba ilmu di Pondok Pesantren Senori-Tuban. Dan secara geografis, pondok Pesantren Senori ini terletak tidak jauh dari tempat tinggalnya di Bangilan, Tuban.

Selepas nyantri di Pondok Pesantren Senori, Hasyim Muzadi juga menyempatkan diri untuk mencatatkan dirinya sebagai santri di Pondok Pesantren Al-Anwar, Sarang-Jawa Tengah. Setelah dari Pondok Pesantren Al-Anwar-Sarang, ia juga nyantri pada Mbah Ma'shum Lasem-Jawa Tengah. Namun tidak berhenti di sini, selepas nyantri di Pondok Pesantren Lasem di bawah asuhan Mbah Ma'shum, yaitu pada tahun 1964 dan diusianya yang ke-18 tahun, Hasyim Muzadi akhirnya dengan tekad dan niat yang bulat melanjutkan pengembaraan intelektualnya dengan mendaftarkan diri untuk melanjutkan di Perguruan Tinggi Fakultas Tarbiyah IAIN Sunan Ampel Malang (sekarang UIN Maulana Malik Ibrahim). ${ }^{14}$

Di kota Apel (sebutan untuk kota Malang) ini, ia tinggal bersama kakaknya, yaitu K.H. Abdul Muchith Muzadi, tepatnya di Bululawang, Malang. Karena pada waktu itu, K.H. Abdul Muchith Muzadi sedang dipindah tugaskan menjadi pegawai administrasi dari IAIN Sunan Kalijaga Yogyakarta ke Institut Agama Islam Negeri (IAIN) Sunan Ampel Malang. Dan berkat peran darinya, Hasyim Muzadi mulai bersentuhan dengan komunitas NU yang pada akhirnya menjadi titik pijak dalam kehidupannya di kemudian hari untuk mengabdikan dirinya bagi NU

\footnotetext{
${ }^{13}$ A. Hasyim Muzadi, Membangun NU Pasca Gus Dur, 4.

${ }^{14}$ Ibnu Anshori, K.H. A. Hasyim Muzadi; Religiusitas, 21.
} 
sampai menjadi ketua umum NU.

K.H. Ahmad Hasyim Muzadi wafat pada hari Kamis, tanggal 16 Maret 2017 pada usia 72 tahun, dan ia meninggal karena sakit dan dikebumikan di komplek Pondok Pesantren Al Hikam II Depok

\section{Islam rabmab li al-'alamin K.H. Ahmad Hasyim Muzadi}

\section{a. Basis Teologis Islam Rabmatan Lil 'Alamin}

Islam merupakan agama yang universal. Universalisme Islam ini harus dipahami sebagai ajaran yang mencakup di dalamnya seluruh pusparagam kehidupan, baik, berhubungan dengan Tuhan Yang Maha Esa, Manusia, dan dengan lingkungan. Gerak ketiganya, harus dijalani dalam keadaan yang berimbang agar mencapai kesempurnaan dan harmonisasi dalam kehidupan di dunia maupun di akhirat. Istilah Islam rabmab li al'alamin merupakan salah satu engel dalam Islam yang sudah ada dalam al-Qur'an. yaitu, sebagaimana firman Allah Swt:

Dan tiadalah Kami mengutus Kamu, melainkan untuk (menjadi) rahmat bagi semesta alam (rabmab li al-'alamin). ${ }^{15}$

Ayat di atas, menurut Hasyim Muzadi menegaskan akan idealisasi dari agama Islam. ${ }^{16}$ Oleh sebab itu Islam harus dipahami secara substansial, agar nilai-nilai yang diajarkannya dapat membumi dalam setiap konteks kehidupan masyarakat. Karena dengan pemahaman yang substansial ini keluhuran dari agama Islam dapat dimanifestasikan dalam setiap gerak kehidupan umat manusia dan seluruh alam semesta. Lebih lanjut ia menegaskan, bahwa konsepsi Islam sebagai agama yang rabmab li al-'alamin sesuai dengan makna kata dari Islam itu sendiri, yaitu adalah damai dan selamat. Sedangkan rabmab li al-'alamin adalah Islam yang kehadirannya di tengah kehidupan masyarakat mampu mewujudkan atau menciptakan terhadap tatanan dunia yang penuh kedamaian dan kasih sayang. Oleh sebab itu, dalam kaitan ini Hasyim Muzadi mengatakan:

${ }^{15}$ al-Qur'an, 21: 107.

${ }^{16}$ A. Hasyim Muzadi, "Islam Rabmatan Lil 'Alamin: Menuju Keadilan dan Perdamaian Dunia (Perspektif Nahdlatul Ulama)", Pidato pengukuhan Doktor Honoris Causa (Dr. HC) dalam bidang Peradaban Islam, IAIN Sunan Ampel Surabaya , (Sabtu, 2 Desember, 2006), 5. 
Orang yang mengaku beragama Islam baruslab senantiasa menunjukan jiwanya yang damai, damai dengan dirinya, damai dengan sesama ummat Islam dan damai dengan sesama ummat manusia. Keadaan jiwanya yang damai tersebut berasal dari makna Islam itu sendiri, yaitu menyerabkan sepenubnya diri, jasad dan pikirnya kepada dan dalam genggaman tangan kuasa Tuhan. Bukan berarti pasrab yang dimaknai tak berbuat apa-apa, tapi kepasrahan total dalam bentuk keyakinan diri sebagaimana dalam setiap shalat kita membaca "Inna shalati wanusuki wamabyaya wa mamati lillahi rabbil "alamin," sesunggubnya shalatku, ibadabku, bidup dan matiku banya untuk Allah semata. ${ }^{17}$

Dengan ungkapan yang lain ia juga menegaskan, bahwa:

Kalau mereka mengamalkan ajaran Islam dengan "benar" maka dengan sendirinya akan mendatangkan rahmat, baik untuk umat Islam maupun untuk seluruh alam. Rahmat merupakan karunia yang dalam agama Islam terbagi menjadi dua bagian. Pertama, rahmat dalam konteks rahman, dan rahmat dalam konteks rahim. rahman dalam konteks rahman, meliputi segala hal, sehingga dengan demikian, orang-orang non-Muslim pun mempunyai hak kerahmaan. Sedangkan sifat rahim, hanya diperuntukkan kepada umat Islam saja. ${ }^{18}$

Dalam konteks ini, Hasyim Muzadi mengajak akan pentingnya untuk mengamalkan ajaran Islam dengan "benar". Karena dalam gugusan realitas seperti yang dijelaskankannya, bahwa merebaknya Islamphobia yang menjadi mainstream dalam pandangan masyarakat Barat, lebih banyak disebabkan atau diakibatkan karena kelirunya seseorang dalam memahami ajaran Islam. Parahnya lagi kondisi tersebut telah mengakibatkan kaum Muslim di dunia dipandang buruk, dan bahkan disebut sebagai pengikut

${ }^{17}$ Lihat, "K.H. Hasyim Muzadi dan Islam Rabmatan Lil 'Alamin", pesan ini, merupakan intisari dari ceramah yang disampaikan oleh K.H. Ahmad Hasyim Muzadi ketika menghadiri acara di Tasikmalaya pada tanggal 09 Januari 2012.

${ }^{18}$ H. A. Hasyim Muzadi, "Islam Rabmatan Lil 'Alamin, 5. Dalam konteks ini, Hasyim Muzadi mengutip penjelasan dari Muhammad 'Ali as-Shabuni yang menjelaskan, bahwa sifat rahman adalah karunia atau kerahmatan Allah Swt. yang berupa rizki yang luas dan kemaslahatan bagi kemanusiaan, serta berlaku umum, baik untuk orang Mukmin maupun orang Kafir. Untuk diskusi lebih lanjut lihat dalam, Muhammad 'Ali as-Shabuni, Tafsir li al-Qur'an al-Karim, Juz I (Makkah: Darul Fikr, 1996), 18-21. 
ajaran agama yang hanya menyebarkan teror dan kekerasan. Untuk itu, guna menjembatani persoalan tersebut, Islam rabmab li al-'alamin harus dihadirkan dalam konteks sosial kemasyarakatan, khususnya dalam penyelesaian pelbagai konflik global yang terjadi selama ini, dan mempunyai pengaruh yang besar terhadap sistem dan sendi kehidupan umat manusia.

Guna menghindari hal di atas, Farid Esack juga menyeru umat Islam untuk menghidupkan dan menegaskan ajaran kasih sayang dalam Islam untuk menyelematkan ajaran suci ini agar tidak dianggap sebagai sumber kekerasan dan umat Islam tidak dituduh memiliki keyakinan yang penuh dengan kemarahan dan dendam kusumat. Lebih lanjut ia menyambung argumennya, bahwa dalam Islam ajaran kasih sayang itu adalah politik kasih sayang yang ditujukan untuk menegakkan keadilan sosial, dengan tidak rela membiarkan penderitaan sosial yang terjadi di tengah-tengah masyarakat, entah mereka beragama Islam ataupun tidak. Karena setiap muslim yang tulus memiliki tugas lanjutan untuk menyelamatkan ajaran kasih sayang Islam agar tidak dikorupsi oleh kalangan fundamentalis. ${ }^{19}$

Oleh sebab itu, dalam rangka mewujudkan Islam yang rabmab li al-'alamin, maka harus bertumpu kepada dua hal. Diantara dua hal tersebut adalah: Pertama, dalam menyelesaikan konflik global, hendaknya lebih menekankan pada pendekatan dialog. Hal ini dimaksudkan untuk mencari dan meneguhkan peran agama sebagai sumber integrasi dalam masyarakat. karena agama mempunyai peranan yang sangat signifikan dalam menata dan membina serta memberi arah dalam kehidupan manusia. Maksudnya adalah, dengan dialog kita dapat menjadikannya sebagai wahana (medium) refleksi yang berdaya kritis ad intra (ke dalam) dan ke luar (ad extra), yang tujuannya untuk mencari jalan kebenaran.

${ }^{19}$ Farid Esack, On Being A Moslem: Fajar Baru Spiritualitas Islam Liberal-Pluralis, “terj.", Nuril Hidayah (Yogyakarta: Ircisod, 2003), 44-46. Dalam konteks ini Farid Esack, mengutip keterangan dari $\mathrm{H}\{$ adist. Dalam sebuah h\}adist dikatakan, bahwa sahabat Umar ibn al-Khattab membawa beberapa tawanan perang ke hadapan Rasulullah Saw. Di antara mereka ada seorang wanita yang lari kesanakemari. Ketika wanita itu melihat seorang anak, ia kemudian menggendong dan menyusuinya. Nabi bertanya kepada para sahabat, Apakah menurutmu wanita ini bisa melemparkan anaknya ke dalam api?" Mereka menjawab, “Tidak". Nabi bersabda, "Allah jauh lebih penyayang pada hamba-Nya daripada wanita itu terhadap anaknya." 
Dialog juga dimaksudkan untuk mengurai persoalan yang terjadi di tengah-tengah masyarakat yang heterogen.

Dialog juga dapat dipahami sebagai suatu bentuk ekspresi dalam mengungkapkan kerukunan dan sekaligus juga meneguhkannya dalam membangun kerja sama dengan pemeluk agama yang berbeda. Tentu, hal ini berangkat dari kenyataan bahwa agama tidak pernah lepas dari perbincangan umat manusia. Maka, dengan demikian adanya suasana dialogis dan penuh toleransi bukan saja bersifat semu dan berada pada suasana yang penuh kepura-puraan, melainkan akan bersifat instrinsik yang tumbuh dalam diri serta berangkat dari kesadaran diri yang pada akhirnya akan membentuk kesadaran yang kukuh dalam sikap.

Adanya toleransi dalam masyarakat madani sangat penting. Bahkan menurut Nurcholish Madjid, salah satu penyebab dari kemunduran umat Islam adalah tidak adanya sikap saling toleransi antara umat Muslim itu sendiri. Umat Islam saling beranggapan bahwa paham atau alirannya yang paling benar. Sehingga mengakibatkan konflik-konflik internal umat yang berkepanjangan. Lebih jauh Nurcholish Madjid berpandangan bahwa, sikap toleran merupakan prasyarat utama dalam menciptakan masyarakat yang beradab (civility), yaitu kesediaan dari masing-masing pribadi untuk menerima berbagai macam pandangan politik dan tingkah laku sosial serta kesediaan untuk menerima pandangan yang sangat penting bahwa tidak selalu ada jawaban yang benar atas suatu masalah. Nurcholish Madjid menganggap bahwa selama ini masyarakat memahami toleransi hanya pada aras prosedural, padahal menurut Nurcholish Madjid persoalan toleransi adalah persoalan prinsip bukan hanya persoalan prosedural semata. ${ }^{20}$

Kedua, implementasi dari Islam sebagai agama yang rabmab li al-'alamin harus dibangun berdasarkan kecerdasan dan ketakwaan. Maksudnya adalah, dalam konteks ini, hendaknya agama harus diposisikan dengan posisi yang seimbang dengan dimensi kemanusiaan, bahkan tujuan agama adalah untuk manusia. Maka, berhubungan dengan hal ini, ia ingin menjelaskan bahwa umat Islam (Muslim) harus bersifat lebih cerdas dalam menghadapi dan menyikapi pelbagai problem yang sedang melandanya. Karena, di dalam setiap persoalan apapun, terdapat banyak

${ }^{20}$ Nurcholish Madjid, Islam Doktrin dan Peradaban: Telaab Kritis Tentang Masalah Keimanan, Kemanusiaan dan Kemoderenan (Jakarta: Paramadina, 1992), 63. 
pihak yang biasanya menunggangi terhadap persoalan tersebut. Sikap cerdas tersebut tentunya harus dipandu dengan sikap takwa kepada Allah Swt. Islam dalam kaitan ini harus diletakkan kembali sebagai agama, yang pantulannya mengandung nilai-nilai kemanusiaan, dan menjadi rahmat bagi seluruh penghuni alam semesta. ${ }^{21}$

Senada dengan di atas, adalah pendapat dari Nurcholish Madjid, ia menyebutnya dengan istilah humanisme religius, di mana agama dan kemanusiaan harus menyatu dengan mesra. Dengan didasarkan pada ayatayat yang ada dalam al-Qur'an, ia mengatakan dengan mengintrodusir beragam ayat al-Qur'an, seperti yang ada dalam bukunya Islam Doktrin dan Peradaban: Telaab Kritis Tentang Masalab Keimanan, Kemanusiaan dan Kemoderenan, ia menuliskannya sebagai berikut:

Karena itu, sebagaimana nilai kemanusiaan tidak mungkin bertentangan dengan nilai keagamaan, demikaianpula nilai keagamaan mustahil berlawanan dengan nilai kemanusiaan. agama tidak dibuat sebagai penghalang bagi kemanusiaan (QS. 22: 78). Maka sesuatu yang sejalan dengan nilai kemanusiaan (bermanfaat untuk manusia) tentu akan bertahan di bumi, sedangkan yang tidak sejalan (tidak berguna bagi manusia, muspra bagaikan 'buih') tentu akan sirna (QS. 13: 17). Agama berasal dari Tuhan, tetapi untuk kepentingan manusia sendiri. Manusia harus berbuat baik demi memperoleh perkenan Tuhan, dan justru dengan memperoleh perkenan atau ridha Tuhan itu manusia berbuat sebaik-baiknya untuk dirinya sendiri (QS. 41: 46). Maka sementara Tuhan tidak perlu kepada manusia, tetapi manusia demi kemanusiaannya sendiri memerlukan ridha Tuhan (QS. 47: 38). Apresiasi Ketuhanan dengan sendirinya menghasilkan apresiasi kemanusiaan (QS. 31: 12). ${ }^{22}$

Untuk itulah, dari pelbagai ayat di atas dapat disarikan bahwa dalam rangka memberikan keseimbangan yang kritis atas pandangan dan sikap keberislaman yang berlebihan dalam memberikan penekanan terhadap dimensi simbolik keagamaan, setiap umat Islam agar saling mengingatkan antar sesama, bahwa dalam Islam ada dimensi kemanusiaan yang tidak kalah pentingnya, yaitu mewujudkan perdamaian dan menciptakan keadilan sosial di muka bumi. Hal ini bukan berarti simbol dan ritual dari

\footnotetext{
${ }^{21}$ Ibnu Ansori, K.H. A. Hasyim Muzadi: Religiusitas, 47.

${ }^{22}$ Nurcholish Madjid, Islam Doktrin dan Peradaban, xiii.
} 
keislaman tidak penting, namun apabila penekanannya terlalu berlebihan terhadap ritualitas, dan mengabaikan pada dimensi yang lain yang bersifat sosial, hal tersebut akan menjadi masalah tersendiri.

Implementasi Islam sebagai agama yang rabmab li al-'alamin menemukan signifikansinya untuk disosialisasikan, dalam kaitan ini, Hasyim Muzadi mengatakan, sebagaimana dikutip oleh As'ad Said Ali, bahwa:

Konsep rabmah li al-alamin ini dalam implementasinya memakai pendekatan tawassut dan i'tidal. Keduanya mempunyai langkah lanjutan, yaitu tawazun (berimbang), tasamub (toleran), dan tashawur (musyawarah/dialog). tawassut atau garis tengah adalah merupakan cara untuk membawakan atau menampilkan agama yang kontekstual. Sedangkan prinsip i'tidal adalah mengangkut kebenaran kognitifnya. Jadi, tawassut wa al-i'tidal merupakan pengertian terhadap yang tepat dan benar, kemudian dibawakan atau ditampilkan di tengah-tengah masyarakat dengan metodologi yang tepat pula. Dengan kata lain, tawassut dan i'tidal sebagai suatu sikap yang mengambil posisi di tengah tetapi jalannya lurus. ${ }^{23}$

Apa yang telah dikemukakan di atas menunjukkan betapa pentingnya untuk menampilkan agama Islam yang moderat. Konstruksi Islam yang moderat tersebut sesuai dengan misi suci dari agama Islam yaitu sebagai rahmat yang tidak hanya bagi umat Islam saja, akan tetapi juga rahmat bagi umat di luar Islam. Ungkapan lain, ajaran yang berorientasi kepada perdamaian dan kehidupan harmonis dalam kebahagiaan, lebih tepat disebut moderat, karena gerakan yang dilakukan lebih menekankan pada sikap memahami dalam arti menghargai dan menghormati terhadap keberadaan yang lain (the other).

Jadi, dengan ini Islam rabmah li al-alamin menjadi semakin jelas ingin meneguhkan bahwa Islam juga dapat menjadi bagian yang integratif dari upaya pembangunan infrasturktur dan keterlibatan agama untuk menciptakan tatanan yang adil dan perdamaian dunia. Karena bagi Hasyim Muzadi terciptanya perdamaian di dunia sejatinya bukan hanya sebagai kebutuhan dalam membangun kesadaran bersama (shared conciuousness), akan tetapi juga sebagai pendekatan bahwa keamanan dan

${ }^{23}$ As'ad Said Ali, Pergolakan di Jantung Tradisi: NU yang Saya Amati (Jakarta: Pustaka LP3ES), 225. 
perdamaian tidak mungkin terjadi tanpa menjamin terhadap keamanan bagi komunitas yang lain. ${ }^{24}$

Cita-cita tersebut tidak akan tercapai atau terwujud tanpa dilandasi pemikiran keagamaan yang moderat (tawassut). Maka, dengan ini wajah Islam yang harus ditampilkan harus bervisikan rabmah li al-'alamin. Karena ekspresi keberislaman yang moderat telah memungkinkan umat Islam untuk membangun harmoni dengan kebudayaan dan tradisi dari agama yang lain.

Dalam perspektif ini, mengacu kepada sumber autentik, al-Qur'an, adanya keragaman (pluralitas) merupakan sunnatullah, hukum alam yang telah ditentukan Allah. Oleh karena itu, tidak ada satu orang atau satu kelompok pun yang dapat menolak, mengabaikan, apalagi menghancurkan sunnatullah. ${ }^{25}$ Dengan kata lain, pluralitas (keragaman) adalah kenyataan sosial, sesuatu yang niscaya dan tidak dapat dipungkiri lagi. Dalam kenyataan sosial, kita telah memeluk agama yang berbedabeda. Pengakuan terhadap adanya pluralisme agama secara sosiologis ini merupakan pluralisme yang paling sederhana, karena pengakuan ini tidak berarti mengizinkan pengakuan terhadap kebenaran teologi atau bahkan etika dari agama lain. Sebagaimana firman Allah Swt:

Dan di antara tanda-tanda kekuasaan-Nya ialah menciptakan langit dan bumi dan berlain-lainan bahasamu dan warna kulitmu. Sungguh pada yang demikian itu benar-benar terdapat tanda-tanda bagi orang yang mengetahui. ${ }^{26}$

Dalam ayat yang lain Allah Swt, juga berfirman:

Hai Manusia, sunggub kami menciptakan kalian dari jenis laki-laki dan perempuan dan menjadikan kalian berbangsa-bangsa dan bersuku-suku supaya kalian saling mengenal. Sunggub orang yang paling mulia di antara kalian di sisi Allab ialah orang yang paling bertakwa. Sunggub Allab Maha Mengetabui lagi Maba Mengenal. ${ }^{27}$

Kedua ayat tersebut, menempatkan keragaman atau pluralitas sebagai syarat determinan (conditio sine qua non) dalam penciptaan makhluk,

${ }^{24}$ H. A. Hasyim Muzadi, "Islam Rabmatan Lil 'Alamin", 4.

${ }^{25}$ H. A. Hasyim Muzadi, Nabdlatul Ulama di Tengah Agenda Persoalan Bangsa (Jakarta: Logos Wacana Ilmu, 1999), 53-54.

${ }^{26}$ al-Qur'an, 30: 22.

${ }^{27}$ al-Qur'an, 49: 13. 
dan pada suatu pengertian yang sangat sederhana, bahwa pluralisme agama adalah suatu sistem nilai yang memandang keberagaman atau kemajemukan agama secara positif sekaligus optimis dengan menerimanya sebagai kenyataan (sunnatullab). Dikatakan secara positif, agar umat beragama tidak memandang pluralitas agama sebagai kemungkaran yang harus dibasmi. Dinyatakan secara optimis, karena kemajemukan agama itu sesungguhnya merupakan sebuah potensi agar setiap umat terus berlomba dalam menciptakan kebaikan di bumi.

Oleh sebab itu, karena Islam mengakui terhadap eksistensi umat manusia yang beragam, tentu Islam sebagai agama tidak pernah menyerukan kebenaran yang dibawanya dengan model atau cara kekerasan atauupun berupa paksaan yang dengan keduanya dapat melanggar nilai-nilai kemanusiaan. Akan tetapi Islam selalu menganjurkan kepada umatnya dalam menyampaikan kebenaran dengan menggunakan caracara yang baik, seperti yang difirmankan oleh Allah Swt:

Serulab (manusia) kepada jalan Tubanmu dengan bikmah dan pelajaran yang baik, dan bantablab mereka dengan cara yang terpuji. Sesunggubnya Tubanmu Dialah yang lebih mengetabui tentang siapa yang tersesat dari jalan-Nya dan Dialah yang lebih mengetabui orang-orang yang mendapatkan petunjuk. ${ }^{28}$

Dengan mengamini terhadap keragaman yang ada, dan menegaskan bahwa Islam hanya bervisikan rahmah li al-'alamin, maka dalam konteks ini konstruksi teologis Islam sebagai rahmah li al-'alamin mempunyai konsekuensi lanjutan yaitu, menjaga dan mempererat tali persaudaraan. Karena hanya menjaga dan mempererat tali persaudaraan, perdamaian antar sesama umat manusia akan terwujud.

Dalam kaitan hal di atas, Hasyim Muzadi mengutip rumusan yang pernah dielaborasi oleh K.H. Ahmad Siddiq. ${ }^{29}$ Ia mengajukan tiga macam

${ }^{28}$ al-Qur'an, 16: 125

${ }^{29}$ K.H. Achmad Siddiq (1926-1991) adalah pengasuh pesantren As-Siddiqiyah Jember. Ia merupakan adik dari K.H. Machfoezh Siddiq. Seorang ulama terkenal yang menjadi ketua NU (1973-1942). Selama 1950-an, K.H. Achmad Siddiq menjadi anggota DPR dan sejak 1970-an beliau bekerja di Departemen Agama. Dia tercatat karena kontribusinya menjadikan NU sebagai suatu organisasi independen yang tidak dengan partai tertentu. Peristiwa ini kemudian dikenal dengan "Kembali ke Khittah NU 1926". 
persaudaraan. Pertama, ukhuwah Islamiyyah, yaitu persaudaraan yang tumbuh dan berkembang atas dasar agama, Islam dalam konteks ini, baik dalam skala lokal, nasional maupun internasional. Kedua, ukhuwah wataniyyah, yaitu persaudaraan yang tumbuh-berkembangkan atas dasar kebangsaan. Ketiga, ukhuwah bashariyyah, yaitu persaudaraan yang tumbuh-berkembang dengan disemangati oleh nilai-nilai kemanusiaan sebagai landasan utamanya. ${ }^{30}$

Maka secara implementatif ketiga bentuk persaudaraan tersebut harus diwujudkan dalam posisi yang berimbang sesuai dengan porsinya masingmasing. Karena dengan ketiganya Islam sebagai agama yang rabmah li al-'alamin akan terealisasi. Untuk itu, dengan memahami substansi ajaran Islam yang rabmah li al-'alamin dengan diringi niat mencari kebenaran wajib untuk dilakukan, serta dengan ditopang oleh sikap membuka diri dan membuka hati terhadap penghargaan yang setinggi-tingginya untuk memperjuangkan nilai-nilai kemanusiaan di muka bumi ini.

\section{b. Pendekatan yang Digunakan}

Dalam rangka membangun gagasan Islam rabmab li al-'alamin, yang erat kaitannya dengan isu-isu kemanusiaan, Hasyim Muzadi menggunakan dua model pendekatan, yaitu: Pertama, pendekatan normatif-idealis. Adapun yang dimaksud pendekatan normatif-idealis adalah bahwa gagasan Islam rahmah li al-'alamin yang dirumuskan oleh Hasyim Muzadi itu mengacu kepada norma-norma atau ajaran yang bersumber dari ajaran Islam yang ideal. Yaitu, al-Qur'an dan Hadist. Kedua sumber ini adalah dua sumber utama yang dijadikan rujukan oleh masyarakat Islam dalam memecahkan pelbagai persoalan, baik dalam ranah ekonomi, politik, maupun yang berhubungan dengan pelbagai persoalan keagamaan.

Dengan kata lain, pendekatan normatif-idealis adalah suatu pendekatan dimana seorang pembaca hendak membaca sebuah persoalan, ia senantiasa merujuk pada yang bersifat ideal normatif (normative ideal approach). Dalam konteks ini dapat dikatakan, bahwa Hasyim Muzadi akan melihat terhadap prinsip-prinsip yang lebih bersifat ideal-normatif. Misalnya, bagaimana al-Qur'an memandang hubungannya dengan Tuhan, dan dengan orang lain.

\footnotetext{
${ }^{30}$ H. A. Hasyim Muzadi, "Islam Rab\}matan Lil 'Alamin”., 8.
} 
Hasyim Muzadi terlebih dahulu melihat sisi ideal normatif yang digambarkan di dalam al-Qur'an. Setelah itu ia baru kemudian melihat bagaimana realitas empiris yang ada dalam masyarakat. Karena bagaimanapun juga prinsip-prinsip dasar dalam agama Islam yang bersifat universal harus berkorelasi dengan konteks sosio-historis kemanusiaan. Misalnya tentang pluralisme, dalam al-Qur'an sudah ditegaskan, akan adanya pluralitas penciptaan di muka bumi ini, baik dari segi budaya, etnis, suku, bahkan agama. Maka dalam konteks ini Hasyim Muzadi ingin menegaskan bahwa hanya lewat pemahaman Islam yang utuh dan benar, seseorang dapat memperoleh pokok-pokok atau nilai-nilai yang ada dalam Islam. Dengan kata lain, mengamini terhadap keragaman (pluralitas) merupakan bagian dari mengamani terhadap sunnatullah. ${ }^{31}$

Kedua, pendekatan historis-empiris. Pendekatan ini digunakan setelah melihat dengan cermat dan seksama bagaimana sebenarnya ajaran idealnormatif Islam. Kemudian selanjutnya bagaimana realitas yang terjadi dalam gugusan empiris. Sehingga dengan ini di satu sisi Hasyim Muzadi mendapatkan gambaran yang teoritis dan tentu bersifat ideal-normatif, namun pada sisi yang lain ia juga memperoleh gambaran yang historis dan empiris dalam masyarakat Islam.

Dalam konteks di atas, Hasyim Muzadi mengatakan, data empiris masih membuktikan bahwa pemahaman pada ajaran atau nilai-nilai dalam Islam masih terdapat disparitas yang sangat lebar antara tataran idealitas dengan realitas. Kata lain, ia ingin menegaskan bahwa masih terjadi gap antara yang idealis-normatif dengan yang historis empiris. Dalam konteks ini, Hasyim Muzadi mencontohkan merebaknya paham radikalisme dalam agama Islam.

Menurutnya, fenomena radikalisme dalam Islam disebabkan oleh banyak faktor, untuk tidak menyebut secara keseluruhan bahwa radikalisme dalam Islam disebabkan oleh adanya pemahaman yang keliru dalam memahami ajaran Islam. Hal ini biasanya didasari atau disebabkan karena mereka memahami Islam dalam bingkai pemahaman yang ekslusif.

Cara pandang yang eksklusif ini memiliki keyakinan bahwa Islam sebagai agama terakhir untuk mengoreksi (kesalahan) agama lain. Bahkan, lebih lanjut ia menjelaskan bahwa cara pandang ini menimbulkan

${ }^{31}$ H. A. Hasyim Muzadi, Nabdlatul Ulama di Tengah Agenda Persoalan Bangsa., 48. 
sikap tidak toleran (intolerance) terhadap keberadaan agama lain. Dengan kata lain, pandangan eksklusivisme ini menurut Hasyim Muzadi yaitu sebuah sikap keagamaan yang menganggap bahwa satu-satunya agama yang benar hanya agama dan keyakinan yang dipeluknya, Islam dalam konteks ini. Sedangkan agama dan kepercayaan lain dianggap sebagai keyakinan yang salah. ${ }^{32}$

Maka jika demikian kenyataannya, berarti ada yang keliru dalam memahami idealitas dari ajaran Islam. Mestinya nilai-nilai yang bersifat universal dalam al-Qur'an, misalnya, kasih sayang, persaudaraan universal, keadilan sosial, perdamaian seperti yang telah dipraktekkan oleh $\mathrm{Nabi}$ Muhammad Saw. sejatinya mampu teraktualisasikan atau dipraktekkan dalam gugusan realitas.

Dengan ungkapan yang lain, bahwa pemahaman kita terhadap ajaran agama terus berkembang, teks-teks sakral memang tidak berubah, tetapi tafsir terhadapnya selalu bergerak, karena pemahaman kita dipengaruhi oleh perubahan zaman dan kondisi. Akan tetapi juga tidak ada tafsir yang mutlak dan mapan untuk semua zaman dan semua tempat. Selain itu, semua orang berhak atas bentuk pemahaman masing-masing. Tidak ada satu pun kelompok warga termasuk ulama, yang punya hak istimewa untuk menafsiri ajaran agama tersebut. Sikap dasar ini merupakan antisipasi terhadap kenyataan akan masa depan agama Islam dan kaum muslimin, seperti telah terbukti dewasa ini yaitu Islam merupakan agama besar, tanpa mengecilkan agama-agama lain.

Dengan demikian, sebagaimana para pendahulunya di NU, Gus Dur Misalnya, yang lebih menekankan pemahaman "ma haula al-nass", bukannya berhenti pada dalam "ma fi al-nass". Begitu juga halnya dengan Hasyim Muzadi, style pemahaman yang demikian mengharuskannya untuk menarik garis demarkasi antara mana yang "pure Islam" dan mana yang "bias kultur Arab".

Untuk itulah Hasyim Muzadi sebagai intelektual-santri yang dibesarkan dalam tradisi Abl al-Sunnab wa al-Jama'ab (Aswaja), Seperti yang digambarkan oleh Husein Muhammad, bahwa pemikiran $\mathrm{Abl}$ alSunnah wa al-Jama'ah (Aswaja) merupakan paham yang sangat toleran

${ }^{32}$ H. A. Hasyim Muzadi, "NU, Radikalisme dan Ummatan Washata”, “dalam”, Islam Madzhab Tengab: Persembaban 70 Tabun Tarmizi Taher, “ed.”, Hery Sucipto (Jakarta: Grafindo Khazanah Ilmu, 2007), 341. 
terhadap puspa-ragam pemikiran. Berbagai pemikiran yang tumbuh di tengah-tengah masyarakat muslim mendapatkan pengakuan yang sangat apresiatif. Dalam kaitan ini, Abl al-Sunnah wa al-Jama'ah (Aswaja) sangat responsive terhadap pelbagai hasil pemikiran dari berbagai madhhab, bukan hanya yang masih eksis tetapi juga terhadap beragam madhhab yang pernah lahir, seperti imam Daud al-Dhahiri, Imam Abdurrahman al-Auza'i dan lain sebagainya. ${ }^{33}$

Maka dalam mengkampayekan Islam rabmah li al-'alamin ia mengambil inspirasinya terhadap dakwah yang dilakukan oleh Walisongo yang mampu "mengawinkan" kearifan lokal dengan universalitas ajaran Islam. Maka, Islam harus dikembangkan sebagai ajaran terbuka dan selalu bersifat universal, Islam yang mampu mengartikulasikan nilai-nilainya pada tradisi lokal yang telah berjalan.

Dengan mengelaborasi pemahaman di atas, maka ia sampai pada satu kesimpulan bahwa Islam dalam konteks sosial, sesungguhnya hanya berbicara mengenai ketentuan-ketentuan dasar atau pilar-pilarnya saja, yang penerjemahan operasionalnya secara detail dan komprehensif tergantung pada kesepakatan dan pemahaman masing-masing komunitas, yang tentu memiliki keunikan berdasarkan keberagaman lokalitas nilai dan sejarah yang dimilikinya. ${ }^{34}$

Dan dalam kerangka berfikir tersebut, Hasyim Muzadi mengamini bahwa ajaran dalam Islam berkoherensi dengan ide-ide kebangsaan. Artinya, kedua ajaran tersebut sama-sama mendorong akan terciptanya satu tatanan masyarakat yang adil, damai, makmur, dan sejahtera sebagaimana termaktub dalam Undang Undang Dasar (UUD) 1945. Begitu juga halnya ajaran Islam yang menganjarkan semangat persaudaraan yang dapat mengantar masyarakat menuju kemarmonisan dan kebersamaan dalam perbedaan. Dengan inilah, dalam perspektif Hasyim Muzadi, agama tidak dibaca dan dihadirkan sebagai ideologi teistik yang dipertentangkan dengan nasionalisme dan sejenisnya. Agama lebih bersifat rujukan moral luhur transformatif yang menjadi pijakan

${ }^{33}$ Husein Muhammad, "Memahami Sejarah Abl al-Sunnab wa al-Jama'ab: Yang Toleran dan Anti-Ektrem”, dalam Kontroversi Aswaja, ed. Imam Baehaqi (Yogyakarta: LKiS, 1999). 40.

${ }^{34}$ A. Hasyim Muzadi, Mengembangkan NU Melalui Penyembuban Luka Bangsa (Jakarta: Logos, 2002), 42-47. 
kokoh dalam menyapa (berdialog) dengan realitas kehidupan secara arif, dewasa, dan kreatif.

Beranjak dari deskripsi di atas, dapat disimpulkan bahwa pola pendekatan normatif-idealis dan historis-empiris tersebut oleh Hasyim Muzadi dilakukan secara dialektis-integratif dan sangat fungsional dalam membaca setiap persoalan. Artinya, keduanya sama-sama dipakai dengan mempertimbangkan atau mengakomodasi terhadap tradisi yang ada. Dengan ungkapan lain, bahwa sesungguhnya pemahaman agama tidak akan lengkap tanpa memahami realitas manusia yang tercermin dalam budayanya. Posisi penting manusia dalam Islam, seperti digambarkan dalam proses penciptaannya yang ruhnya merupakan tiupan dari ruh Tuhan, memberikan indikasi bahwa manusia menempati posisi penting dalam mengetahui tentang Tuhan. Dengan demikian pemahaman agama secara keseluruhan tidak akan tercapai tanpa memahami separuh dari agama yaitu manusia. Barangkali tidak berlebihan untuk menyebut bahwa realitas manusia sesungguhnya adalah realitas ketuhanan yang empiris. Di sinilah letak pentingnya memadukan pendekatan normatifidealis dan historis-empiris seperti yang telah diimplementasikan oleh Hasyim Muzadi.

\section{Penutup}

Islam rabmah li al-'alamin menurut K.H. Ahmad Hasyim Muzadi merupakan suatu terminologi yang diambil dari dalam al-Qur'an. Sebagai agama yang bervisikan rabmah li al-'alamin, tentu hal ini harus dipahami sebagai ajaran atau pesan dari Yang Maha Agung untuk mewujudkan misi perdamaian, agar mencapai kesempurnaan dan harmonisasi, serta kebahagiaan sejati dalam kehidupan di dunia maupun di akhirat. Dalam pengertian ini, Islam rahmah li al-'alamin. Sementara itu, gagasan ini muncul sebagai bentuk reaksi atau tanggapan dalam rangka menyapih lara yang sedang melanda masyarakat Islam, utamanya stigmatisasi yang dialamatkan terhadap agama Islam, sebagai agama yang dalam ajarannya terkandung benih-benih yang memupuk seorang muslim untuk melakukan tindak kekerasan.

Dengan demikian, rahmah li al-'alamin yang dirumuskannya oleh Hasyim Muzadi adalah model berislam yang lebih menekankan pada sisi 
substansial ajaran Islam daripada menekankan pada sisi formalitasnya. Dengan ungkapan lain, bahwa hal ini mempunyai pemahaman dalam rangka membumikan ajaran Islam seharusnya dimulai dengan membangun kesadaran diri para pemeluknya, sehingga dengan demikian dapat menciptakan kehadiran Islam yang ramah, yang tercermin dari sikap dan perilaku para pemeluknya. Itulah sebabnya sangat perlu bahwa setiap agama dan para penganutnya di negeri ini selalu waspada dan bersikap kritis terhadap setiap upaya yang ingin menekankan pada aspek institusionalisasi Islam. 


\section{Daftar Pustaka}

Anshori, Ibnu. K.H. A. Hasyim Muzadi; Religiusitas E Cita-Cita Good Governance. Sidoarjo: Citra Media, 2004.

Khuluq, Lathiful. Fajar Kebangunan Ulama; Biografi K.H. Hasyim Asy'ari. Yogyakarta: LKiS, 2000.

Machasin. Islam Dinamis Islam Harmonis; Lokalitas, Pluralisme, Terorisme. Yogyakarta: LKiS, 2011.

Madjid, Nurcholish. Islam Doktrin dan Peradaban: Sebuah Telaah Kritis tentang Masalah Keimanan, Kemanusiaan, dan Kemoderenan. Jakarta: Paramadina, 1992.

Muzadi, Ahmad Hasyim. Membangun NU Pasca Gus Dur; Dari Sunan Bonang sampai Paman Sam. Jakarta: PT Gramedia Widiasarana Indonesia, 1999.

. Nabdlatul Ulama di Tengah Agenda Persoalan Bangsa. Jakarta: Logos, 1999.

. Mengembangkan NU Melalui Penyembuhan Luka Bangsa. Jakarta: Logos, 2002.

. NU Dikritik dan Di sanjung. Surabaya: PWNU Jawa Timur, 1999.

"Terorisme dan Kebijakan Luar Negeri Amerika Serikat", "dalam", Islam dan Terorisme: Dari Minyak Hingga Hegemoni Amerika, “ed.”, Maulani Z.A. Yogyakarta: UCY Press, 2005.

. "Bila Syariah Harfiah, Negara Retak" Aula No. 02 Tahun XXVIII. Juni, 2006.

. "Globalisasi Rabmatan Lil 'alamin" Jawa Pos, 09 Oktober 2006.

. "Timur Tengah dan Prospek Islam”, Republika, 04 September 2006.

. "Islam Rabmatan Lil Alamin; Menuju Keadilan dan Perdamaian Dunia", (Pidato Pengukuhan Dr. (HC), Surabaya: IAIN Sunan Ampel, 2006. 
. "NU, Radikalisme dan Ummatan Washato", dalam Islam Madzab Tengah; Persembahan 70 Tahun Tarmizi Taher, ed. Hery Sucipto. Jakarta: Grafindo Khazanah Ilmu, 2007.

. "Kembalilah ke Gaya Walisongo", Majalah Duta Masyarakat, Edisi II. April-Mei, 2011.

. "Memperkuat NU, Memperkuat NKRI" Aula, No. 04 Tahun XXXIII. April, 2011.

. "Membumikan Pancasila”, Seputar Indonesia, 07 Juni 2011.

Said Ali, As'ad. Pergolakan di Jantung Tradisi: NU yang Saya Amati. Jakarta: LP3ES, 2008.

Shodiq, Muhammad. Dinamika Kepemimpinan NU; Refleksi Perjalanan K.H. Hasyim Muzadi. Surabaya: Lajnah Ta'lif Wa Nasyr (LTN) NU Jawa Timur, 2004.

Stepan, Alfred. Religion, Democracy and the "Twin Tolerations. Journal of Democracy, Vol. 1. No. 4. Oktober, 2000.

Sutarto, Ayu. Menjadi NU Menjadi Indonesia: Pemikiran K.H. Abdul Muchith Muzadi. Surabaya: Khalista, 2008. 